\title{
Active Metal Brazing and Characterization of Brazed Joints in Titanium to Carbon-Carbon Composites
}

\author{
M. Singh and T.P. Shpargel \\ QSS Group, Inc., \\ NASA Glenn Research Center \\ Cleveland, $\mathrm{OH} 44135$ \\ G. N. Morscher \\ Ohio Aerospace Institute \\ NASA Glenn Research Center \\ Cleveland, $\mathrm{OH} 44135$ \\ R. Asthana \\ Technology Department \\ University of Wisconsin-Stout \\ Menomonie, WI 54751
}

\begin{abstract}
The Ti-metal/C-C composite joints were formed by reactive brazing with three commercial brazes, namely, $\mathrm{Cu}-\mathrm{ABA}$, TiCuNi, and TiCuSil. The joint microstructures were examined using optical microscopy and scanning electron microscopy (SEM) coupled with energy dispersive spectrometry (EDS). The results of the microstructure analysis indicate solute redistribution across the joint and possible metallurgical bond formation via interdiffusion, which led to good wetting and spreading. A tube-on-plate tensile test was used to evaluate joint strength of Titube/C-C composite joints. The load-carrying ability was greatest for the $\mathrm{Cu}-\mathrm{ABA}$ braze joint structures. This system appeared to have the best braze spreading which resulted in a larger braze/C-C composite bonded area compared to the other two braze materials. Also, joint loadcarrying ability was found to be higher for joint structures where the fiber tows in the outer ply of the C-C composite were aligned perpendicular to the tube axis when compared to the case where fiber tows were aligned parallel to the tube axis.
\end{abstract}




\section{INTRODUCTION}

Carbon-carbon (C-C) composites are extensively used for the nose cap and leading edges of the space shuttle, rocket nozzles exit cones and heat shield for ballistic missiles [1]. For the space exploration systems, high conductivity C-C composites have been developed for applications in lightweight radiators and recuperators of the thermal management systems and for spacecraft structures. Most such applications will require joining C-C to metals. Robust assembly and integration technologies will, therefore, play an essential role in the development and manufacture of parts using novel and conventional carbon-base materials [2-4]. Carbon-carbon has been brazed using $\mathrm{Ag}, \mathrm{Au}$ and $\mathrm{Cu}$-base filler metals for moderate use temperatures, and $\mathrm{Zr}$ and $\mathrm{Hf}$ metals, and $\mathrm{HfB}_{2}$ and $\mathrm{MoSi}_{2}$ powders for very high use temperatures [5-7].

In this paper, three commercial active metal brazes ( $\mathrm{Cu}-\mathrm{ABA}$, TiCuNi, and TiCuSil) were used to create $\mathrm{C}-\mathrm{C} / \mathrm{Ti}$ joints. The microstructure and composition of the brazed joints were examined by optical and scanning electron microscopy (SEM) coupled with EDS. The effect of braze composition and processing conditions on the interfacial microstructure and composition of the joint regions is presented in light of the wetting and spreading of reactive brazes. Joint strength was characterized to examine the effect of the bonded area and the orientation of the $\mathrm{C}$ fibers in the outer ply on the strength.

\section{EXPERIMENTAL PROCEDURE}

The carbon-carbon composites used in this study were obtained from C-C Advanced Technologies, Inc. (C-CAT) Fort Worth, TX. These composites were made from T-300 C fibers and resin-derived carbon matrix. The composite panels were sliced into $2.54 \mathrm{~cm} \mathrm{x} 1.25 \mathrm{~cm} \mathrm{x}$ $0.25 \mathrm{~cm}$ pieces. Commercially pure Ti plates from Titanium Metals Corporation (TIMET), MO, were also cut into slices of the same size, and joined to $\mathrm{C}-\mathrm{C}$ using intervening braze foils. The following commercial brazes obtained from Morgan Advanced Ceramics, Inc., CA, were used for joining C-C composites to Ti: $\mathrm{Cu}-\mathrm{ABA}$, TiCuNi, and TiCuSil. The composition, and physical and mechanical characteristics of these brazes are summarized in Table 1. The braze foil thickness was $\sim 50 \mu \mathrm{m}$. All the materials were ultrasonically cleaned in acetone for $10 \mathrm{~min}$. prior 
to their use. The braze foil, cut to the size of Ti and C-C plates, was sandwiched between them, and a normal load of $0.30 \mathrm{~N}$ was applied to the assembly to hold them together. The assembly was heated to the brazing temperature under vacuum, isothermally held for 5 min., and then cooled to room temperature. The brazed samples were cut, mounted in epoxy, polished, and examined using optical and scanning electron microscopy (SEM) coupled with energy dispersive X-ray spectroscopy (EDS).

For mechanical testing, a "tube tensile test" was developed [8] to evaluate the effectiveness of the three braze approaches for tube/plate braze applications. $\mathrm{C}-\mathrm{C}$ composite pieces, $2.54 \mathrm{~cm} \mathrm{x}$ $1.25 \mathrm{~cm} \times 0.25 \mathrm{~cm}$, were brazed to $1.25 \mathrm{~cm}$ diameter Ti tubes. The tensile test (Figure 1) consisted of mounting the flat plate on a rigid bar and pulling the tube in tension with a universal testing machine (Instron 4502, Canton, MA). The peak load corresponded to the load-carrying ability of the joint. The fracture surface was examined to determine the fracture location and nature and extent of bonding.

\section{RESULTS AND DISCUSSION}

\subsection{Interface Microstructure}

Figures 2 through 7 display the interface microstructure of the joints made using the three braze materials. Both low- and high-magnification views of the $\mathrm{C}-\mathrm{C} / \mathrm{braze}$ interface for each of the braze materials indicate an intimate contact between the carbon and the braze. The interfaces are free of commonly-found structural defects such as microvoids and porosity. An interfacial interphase appears to have preferentially precipitated on the carbon surface in all the cases (Figs. $3,5 \& 7)$. The EDS analysis across the interface regions shows evidence of solute redistribution during brazing. High Ti concentrations were detected at the interface in $\mathrm{C}-\mathrm{C} / \mathrm{TiCuNi}$ (Fig. 5a) and C-C/TiCuSil (Fig. 7a) joints, suggesting possible formation of a Ti-rich interphase, such as $\mathrm{TiC}_{1-\mathrm{x}}$, which bonds well to both the carbon and the braze. At the braze/Ti interface, some dissolution of the metal in the molten braze appears to have occurred, leading to near-interfacial changes in the composition. Overall, the interfaces appear to be microstructurally sound, and well-bonded due to interdiffusion of solutes and the formation of secondary phases. 
The formation of $\mathrm{TiC}$ in Ti-containing brazes in contact with carbon is thermodynamically favorable. The Gibb's free energy change for $\mathrm{TiC}$ formation from the reaction $\mathrm{Ti}+\mathrm{C} \rightarrow \mathrm{TiC}$ in the temperature range $920-1050^{\circ} \mathrm{C}$ is -174 to $169 \mathrm{~kJ}$, which indicates that $\mathrm{TiC}$ formation is highly likely. Thermodynamic calculations $[9,10]$ also show that sub-stoichiometric carbides such as $\mathrm{TiC}_{0.95}, \mathrm{TiC}_{0.91}, \mathrm{TiC}_{0.80}, \mathrm{TiC}_{0.70}, \mathrm{TiC}_{0.60}$ and $\mathrm{TiC}_{0.48}$ could form from $\mathrm{Cu}$ alloys in which the activity of $\mathrm{Ti}$ is greater than 0.1 . As the solubility of $\mathrm{Ti}$ in $\mathrm{Cu}$ at the brazing temperatures of 920 $1050^{\circ} \mathrm{C}$ is high, its activity coefficient may be large enough to cause the formation of these carbides. With reference to the $\mathrm{Cu}-\mathrm{ABA}$ braze, it should be noted that it contains $\mathrm{Si}$ in addition to $\mathrm{Ti}$, and both silicon carbide and titanium carbide could form from the reaction of $\mathrm{Si}$ and $\mathrm{Ti}$ with carbon. The Gibb's free energy change for $\mathrm{SiC}$ formation $(\mathrm{Si}+\mathrm{C} \rightarrow \mathrm{SiC})$ in the temperature range 920 to $1050^{\circ} \mathrm{C}$ is -62.4 to $-61.1 \mathrm{~kJ}$, which suggests that $\mathrm{SiC}$ formation during brazing is thermodynamically possible.

\subsection{Braze Spreading}

The interface microstructures presented in Figs. 2-7 show that the Ti-metal/braze/C-C joints are free of interfacial micro defects, and exhibit excellent physical contact and good metallurgical bonding. The literature data compiled in Table 2 and Fig. 8(a) show that Ti additions to $\mathrm{Sn}, \mathrm{Ag}, \mathrm{Cu}$, and $\mathrm{CuSn}$ alloys sharply decrease the contact angle, $\theta$, and promote braze spreading on carbon. Usually, short brazing times suffice for maximum spread; for example, $\theta$ approaches $0^{\circ}$ in $5 \mathrm{~min}$. for $\mathrm{Cu}-12 \% \mathrm{Ti}$ melt in contact with vitreous $\mathrm{C}$ [11]. Thus, pure $\mathrm{Cu}$ and $\mathrm{Ag}$ do not wet graphite $\left(\theta \sim 137^{\circ}-140^{\circ}\right)$, but the addition of Ti $[9,11,12]$ and/or $\mathrm{Si}$ [13] improves the wetting through the formation of carbides $\mathrm{TiC}$ and $\mathrm{SiC}$ at the interface. One of our brazes, Copper-ABA, contained $\mathrm{Si}$ besides $\mathrm{Ti}$, and $\mathrm{Si}$ is known to react with and lower the contact angle on carbon $\left(\theta \sim 0^{\circ}\right.$ for $\left.\mathrm{Si} / \mathrm{C}[14,15]\right)$. In the case of $\mathrm{Ti}$ as a reactive solute in braze, both $\mathrm{TiC}$ and substoichiometric titanium carbides with $\mathrm{C} / \mathrm{Ti}$ ratio $<0.65$ could form. These carbides are readily wetted by $\mathrm{Cu}[9]$.

The spreading and bonding behaviors depend also upon the reaction layer morphology, which, in turn, is sensitive to porosity in the substrate. For example, with porous graphite, Naidich and coworkers [12,16] and Sobczak et al [17] note that $\mathrm{Cu}$-Ti alloys both wet and impregnate the graphite. With $\mathrm{Ti}$ in the braze, the $\mathrm{TiC}$ reaction layer is discontinuous with a non-homogenous 
structure [17] that permits penetration of porous carbon by the melt. However, the interface microstructures of our joints displayed in the photomicrographs of Figs. 2 through 7 do not show evidence of braze penetration in the $\mathrm{C}-\mathrm{C}$ substrate, which is presumably due to the higher density and relatively low open porosity of our C-C substrate materials in comparison to those used in ref. [17]. Besides Ti carbides, other interfacial compounds could also form at the interface in Ticontaining brazes; for example, a wettability-enhancing, metal-like interfacial layer of TiO has been reported in the literature [18]. The formation of this layer in our joints is not unlikely especially because stable oxides of Ti form even at oxygen partial pressures as low as $\sim 10^{-28}$ atm., which will most likely exist in the brazing atmosphere.

Thus, even though the base metals copper and silver are inert to carbon and oxygen, reactive $\mathrm{Ti}$ possesses high affinity toward both oxygen and carbon. Likewise, the nickel in TiCuNi also has a higher affinity for carbon than $\mathrm{Cu}, \mathrm{Au}$ and $\mathrm{Ag}$, and has been found to segregate at the carbon/ metal interface. Even though there are no stable carbides in the Ni-C system, many workers have reported the formation of a metastable nickel carbide due to interaction of liquid Ni with solid C; this leads to the reasonably good wettability with relatively low contact angles $\left(68-90^{\circ}[15]\right)$ of $\mathrm{Ni}$ on carbon. However, as the principal constituent of $\mathrm{TiCuNi}$ is $\mathrm{Ti}(\sim 70 \%)$ which strongly reacts with the carbon, formation of nickel carbide in our joints is less probable.

In the case of $\mathrm{TiCuSil}$, the Ag-Cu-Ti system contains a liquid miscibility gap. The phase diagram shows that eutectic $\mathrm{Ag}-\mathrm{Cu}$ alloys containing more than 5 at\% Ti divide the alloy into a Tidepleted liquid and a Ti-rich liquid, the latter containing greater than 5 at\% Ti (e.g., more than 25 at $\% \mathrm{Ti}$ at $950^{\circ} \mathrm{C}$ ). This Ti-rich liquid will react with the carbon substrate to form a metallurgical bond. The Ti-depleted liquid forms $\mathrm{Ag}[\mathrm{Cu}, \mathrm{Ti}]$ solid solution upon solidification, and eutectic type phase mixtures. The Ti-rich liquid solidifies to yield $\mathrm{Ag}[\mathrm{Cu}]$ precipitates and intermetallics such as $\mathrm{AgTi}, \mathrm{Ti}_{2} \mathrm{Cu}_{3}$, and $\mathrm{TiCu}_{2}$. In addition, $\mathrm{TiO}_{2}$ formation due to partial oxidation of $\mathrm{Ti}$ is possible.

The braze spreading on C-C composites could be understood in terms of the surface tension and contact angle data of the individual braze constituents. The very large values of the surface tension, $\sigma_{\mathrm{lv}}$, of $\mathrm{Ag}, \mathrm{Ni}$ and $\mathrm{Cu}$ of the braze at their melting points show that these metals in pure 
state will probably not wet the C-C. For example, $\sigma_{\mathrm{lv}}$, of $\mathrm{Ni}$ is $1796 \mathrm{~N} / \mathrm{m}$ (at $1455^{\circ} \mathrm{C}$ ), of $\mathrm{Ag}$ is $925 \mathrm{~N} / \mathrm{m}$ (at $960^{\circ} \mathrm{C}$ ), and of $\mathrm{Cu}$ is $1330 \mathrm{~N} / \mathrm{m}$ (at $1086^{\circ} \mathrm{C}$ ), respectively [20]. The temperaturecorrected surface tension data [19] also do not show any significant drop in $\sigma_{\mathrm{lv}}$ of these metals at higher temperatures. The addition of $\mathrm{Ti}$ to the braze improves the wetting and spreading (provided Ti does not oxidize during brazing); such effects of $\mathrm{Ti}$ on the wettability have been observed in many systems [20]. The wetting and spreading of Ti-containing braze on C-C is excellent even at relatively small Ti contents $[16,21]$ which led to good physical contact as noted from the data of Fig. 8. This was also observed by the authors in an earlier work [21].

\subsection{Mechanical Properties}

Figure 9 shows the average fracture loads for the joint structures for the three different braze compositions for composites that were either oriented with the surface ply fiber tows aligned parallel to the tube axis or perpendicular to the tube axis. All of the fractures occurred within the surface ply of the C-C composite and not within the braze itself indicating good chemical bonding of the braze compositions to the composite. Two factors definitely contribute to the load-carrying ability of these joint structures [8]: the bonded area of the braze material and the fiber-tow orientation. The joint structures with the $\mathrm{Cu}$-ABA braze had the highest load-carrying ability because the bonded area of the braze material was largest (Figure 10). Presumably, this was due to superior spreading properties of this braze material. In addition, on average, the composite plates with fiber tows in the outer ply aligned perpendicular to the tube axis had higher load carrying ability than composite plates with outer ply fiber tows aligned parallel to the tube axis for all three braze compositions (Figure 9). Evidently, the higher load-carrying ability is due to the greater number of tows that are brazed to the Ti-tube when fiber tows are oriented perpendicular to the tube axis compared to the parallel orientation.

\subsection{Thermal Considerations}

The thermal response of the $\mathrm{C}-\mathrm{C} / \mathrm{Ti}$ joints is important for thermal management applications (e.g., spacecraft radiators, heat exchangers). $\mathrm{Cu}, \mathrm{Ag}$ and $\mathrm{Ti}$ were the principal constituents of our brazes, with the $\mathrm{Ag}$ and $\mathrm{Cu}$ brazes (Cu-ABA and TiCuSil) containing $\mathrm{Ti}$ as an active metal. While Ti alloying usually decreases the thermal conductivity, the relatively small $\mathrm{Ti}$ content of our $\mathrm{Ag}$ and $\mathrm{Cu}$ brazes may not be detrimental to the braze conductivity. On a 
positive note, Ti additions to $\mathrm{Cu}$ decrease the melting point of $\mathrm{Cu}$, which makes braze spreading easier, leading to the formation of a good $\mathrm{C}-\mathrm{C} / \mathrm{Ti}$ joint [21].

The thermal conductivity of TiCuSil is $219 \mathrm{~W} / \mathrm{m} . \mathrm{K}$ (Table 1) which compares favorably with that of 3D C-C composites (quoted as 60-190 W/m.K [1], although with a Cu-ABA joint (conductivity $38 \mathrm{~W} / \mathrm{m} . \mathrm{K}$ ), higher thermal resistance to heat dissipation may occur. A large thermal discontinuity will be encountered at the braze/Ti interface as well because the conductivity of commercially pure $\mathrm{Ti}$ is only $16.0 \mathrm{~W} / \mathrm{m}$. K. It will be necessary to perform thermal management tests on joint assemblies in the geometric configuration that they will be used in an actual radiator or heat exchanger to understand how these interfaces will modulate the heat flow.

A comparison of the room-temperature values of CTE of Cu-ABA and TiCuSil (Table 1) with the CTE of C-C (quoted as $0-1.0 \times 10^{-6} / \mathrm{K}$ over $20-250^{\circ} \mathrm{C}$, and $2.0-4.0 \times 10^{-6} / \mathrm{K}$ over $20-2500^{\circ} \mathrm{C}$ for the 3D composites [1]) shows that the CTE mismatch $(\Delta \alpha)$ is very large, and will likely result in large thermal stresses due to differential expansion (contraction) at the $\mathrm{C}$-C/braze interface during brazing and service. However, the relatively large ductility (Table 1) of brazes will likely accommodate the thermal stresses, thus preventing interfacial cracking and joint failure. This agrees with the absence of interfacial cracking and disjoining in Figs. 2-7. A simple calculation shows that the thermal strain, $\Delta \alpha \Delta \mathrm{T}$, for a brazing temperature range of $1050^{\circ} \mathrm{C}$ to room temperature $\left(25^{\circ} \mathrm{C}\right)$, will be $1.69 \times 10^{-2}, 1.59 \times 10^{-2}$, and $1.77 \times 10^{-2}$, respectively, for the $\mathrm{Cu}-\mathrm{ABA}$, TiCuSil, and TiCuNi joints. These thermal strains will likely exceed the yield strain (on the order of $10^{-3}$ ) of our braze alloys, which suggests that plastic yielding at the interface may be likely even if some of the alloying elements in the braze provide solid-solution hardening. The interface between the Ti metal and the braze has a smaller CTE mismatch (CTE of commercial purity $\mathrm{Ti}$ is $8.6 \times 10^{-6} / \mathrm{K}$ ) than the CTE mismatch at the $\mathrm{C}-\mathrm{C} /$ braze interface. As a result, less severe thermal stress concentration is anticipated at this interface.

\section{CONCLUSIONS}

The interface microstructure in Ti-metal/C-C composite joints formed by reactive brazing with $\mathrm{Cu}-\mathrm{ABA}$, TiCuNi, and TiCuSil were examined using optical microscopy, and scanning electron 
microscopy (SEM) coupled with energy dispersive spectrometry (EDS). Evidence of solute redistribution across the joint during brazing, and possible metallurgical bond formation via interdiffusion led to good wetting and bonding. The mechanical characterization of the joints using a Ti-tube/C-C plate joint tensile test indicated that both the area of bonding and the orientation of the $\mathrm{C}$ fiber tows in the outer ply of the harness satin weave at the mating surface affected the joint strength. The $\mathrm{Cu}-\mathrm{ABA}$ braze material had the best spreading (bonded area) for the Ti-Tube/C-C joint structures which enabled the highest joint strengths. Also, joint structures with outer fiber tows oriented perpendicular to the tube axis had greater load-carrying ability than joint structures with outer fiber tows oriented parallel to the tube axis for all three braze compositions.

\section{ACKNOWLEDGEMENT}

The authors would like to thank Mr. Mike Halbig and Mr. J. Douglas Kiser for helpful comments on the manuscript. R. Asthana acknowledges the award of a NASA/ASEE Faculty Fellowship for research at NASA Glenn Research Center during June-Aug 2004.

\section{REFERENCES}

1. R. Taylor, "Carbon-matrix composites"; in Comprehensive Composite Materials, 4 pp. 387 426, Elsevier Science Ltd., Boston, 2000.

2. D. Lewis III and M. Singh, in ASM Handbook, 21 (2001) 668-673 ASM Int., Mater. Park, OH.

3. D. Goodman and R. Singler, NASA CR 97, 206679 (1998).

4. M.G. Nicholas, Joining of Ceramics, (1990) 73-93, Chapman \& Hall, London.

5. P.G. Valentine and P.W. Trester in Proc., $15^{\text {th }}$ Conference on Metal-Matrix, Carbon, and Ceramic-Matrix Composites, NASA CP-3133, Part I, J.D. Buckley (ed.) (1990) 39-55.

6. "Joining of carbon-carbon and ceramic-matrix composites", Materials Innovations Lab Presentation, Inter-agency Planning Group Meet, S. Yalof (ed.); IDA Memo Report M-312, T.F. Kearns (ed.) (April 1987).

7. P. Dadras, Proceedings of the $14^{\text {th }}$ Conf. Metal-, Carbon- and Ceramic-Matrix Compos., NASA CP 3097, Part 2, J.D. Buckley (ed.) (1990).

8. G.N. Morscher, R. Asthana, M. Singh, and T. Shpargel, "A Simple Test to Determine the Effectiveness of Different Braze Compositions for Joining Ti-Tubes to $\mathrm{C} / \mathrm{C}$ Plates" (to be submitted).

9. R. Standing and M. Nicholas, J. Mater. Sci., 13 (1978) 1509-1514.

10. E.K. Storms, Refractory Carbides, Academic Press, New York, 1967. 
11. J.G. Li, J. Mater. Sci. Lett., 11 (1992) 1551-1554.

12. N. Grigorenko, V. Poluyanskaya, N. Eustathopoulos, and Y. Naidich, in Interfacial Sci. of Ceram. Joining, Bellosi et al (eds.), Kluwer Acad. Publ., Boston (1998), 69-78.

13. O. Dezellus, F. Hodaj and N. Eustathopoulos, in Trans. JWRI, Osaka Univ. (Japan), N. Eustathopoulos, K. Nogi and N. Sobczak (eds.), 30 (2001) 75-84.

14. J. T. Whalen and A.T. Anderson, J. Amer. Ceram. Soc., 34[4] (1976) 378-383.

15. M. Humenik, Jr. and W.D. Kingery, J. Amer. Ceram. Soc., 37[1] (1954) 18-23.

16. N. Grigorenko, V. Poluyanskaya, N. Eustathopoulos, and Y. V. Naidich, in Proc. $2^{\text {nd }}$ Int. Conf. on High-Temp. Capillarity, N. Eustathopoulos and N. Sobczak (eds.), Foundry Res. Inst. (Krakow) (1997) 27-35.

17. N. Sobczak, J. Sobczak, M. Ksiazek, W. Radziwill and J. Morgiel, in Proc. $2^{\text {nd }}$ Int. Conf. on High-Temp. Capillarity, Eustathopoulos and Sobczak (eds.), Foundry Research Institute (Krakow) (1997) 97-98.

18. V.M. Pervertailo, O.B. Loginova, and N.G. Bagno, 143-147 in Trans. JWRI, Osaka Univ. (Japan), N. Eustathopoulos, K. Nogi and N. Sobczak (eds.), 30 (2001) 143-147.

19. B.J. Keene, Int. Mater. Revs., 38(4) (1993) 157-192.

20. Y.V. Naidich, in Progress in Surface and Membrane Science, Cadenhead and Danielli (eds.), Academic Press, New York (1981).

21. M. Singh, T.P. Shpargel, G. Morscher and R. Asthana, in Proc. of the $5^{\text {th }}$ International Conference on High-Temperature Ceramic-Matrix Composites (HTCMC-5), M. Singh, R.J.

Kerans, E. Lara-Curzio, and R. Naslain (eds.), The Amer. Ceramic Soc., Westerville, OH (2005) 457-462. 
Table 1. Physical and Mechanical Properties of Cu-ABA, TiCuNi, and TiCuSil Brazes

\begin{tabular}{|c|c|c|c|c|c|c|c||}
\hline Braze & Composition & $\begin{array}{c}\mathbf{T}_{\mathbf{L}}, \\
\mathbf{K}\end{array}$ & $\begin{array}{c}\mathbf{T}_{\mathbf{S}} \\
\mathbf{K}\end{array}$ & $\mathbf{C T E}, \mathbf{1 0}^{-\mathbf{6}} / \mathbf{K}$ & $\begin{array}{c}\text { Thermal Cond., } \\
\mathbf{W} / \mathbf{m} . \mathbf{K}\end{array}$ & $\begin{array}{c}\text { Y.S., } \\
\mathbf{M P a}\end{array}$ & \% Elong. \\
\hline $\mathrm{Cu}-\mathrm{ABA}$ & $\begin{array}{c}92.8 \mathrm{Cu}, 3 \mathrm{Si}, \\
2 \mathrm{Al}, 2.25 \mathrm{Ti}\end{array}$ & 1300 & 1231 & 19.5 & 38 & 279 & 42 \\
\hline $\mathrm{TiCuNi}$ & $\begin{array}{c}70 \mathrm{Ti}, 15 \mathrm{Cu}, \\
15 \mathrm{Ni}\end{array}$ & 1233 & 1183 & 20.3 & -- & -- & -- \\
\hline TiCuSil & $\begin{array}{c}68.8 \mathrm{Ag}, 26.7 \\
\mathrm{Cu}, 4.5 \mathrm{Ti}\end{array}$ & 1173 & 1053 & 18.5 & 219 & 292 & 28 \\
\hline
\end{tabular}

Table 2. Contact Angles of Various Ti-Containing Alloys on Carbon (Ref. [9,11,12,15,16,20])

\begin{tabular}{|l|c|c|}
\hline \multicolumn{1}{|c|}{ Alloy } & Temp., $\mathbf{K}$ & Contact Angle, deg. \\
\hline $\mathrm{Ag}-0.1 \mathrm{wt} \% \mathrm{Ti}$ & 1273 & $45^{1}, 85^{2}$ \\
\hline $\mathrm{Ag}-0.45 \mathrm{wt} \% \mathrm{Ti}$ & 1273 & $5^{1}$ \\
\hline $\mathrm{Ag}-1.0 \mathrm{wt} \% \mathrm{Ti}$ & 1273 & $7^{2}$ \\
\hline $\mathrm{NiPd}-50 \mathrm{wt} \% \mathrm{Ti}$ & 1523 & $16^{3}$ \\
\hline $\mathrm{Ni}-45 \mathrm{wt} \% \mathrm{Pd}$ & 1523 & $137^{3}$ \\
\hline $\mathrm{Cu}-12 \mathrm{at} \% \mathrm{Ti}$ & 1350 & $0^{3}$ \\
\hline $\mathrm{Cu}-17.5 \mathrm{wt} \% \mathrm{Ti}$ & 1373 & $10^{4}$ \\
\hline $\mathrm{CuSn}-50 \mathrm{at} \% \mathrm{Ti}$ & 1473 & $11^{3}$ \\
\hline
\end{tabular}

${ }^{1}$ diamond, ${ }^{2}$ graphite, ${ }^{3}$ vitreous $\mathrm{C},{ }^{4}$ porous graphite. 


\section{C/C composite}

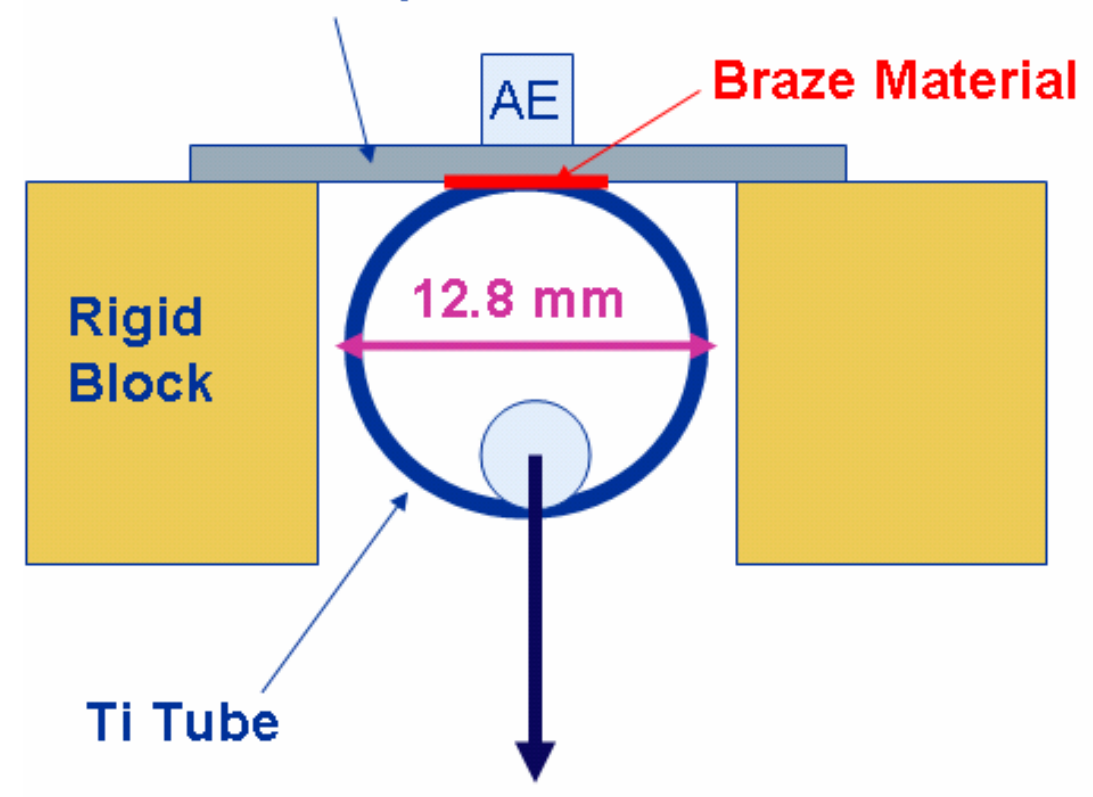

Applied Load

Figure 1: Schematic of tube tensile test. 


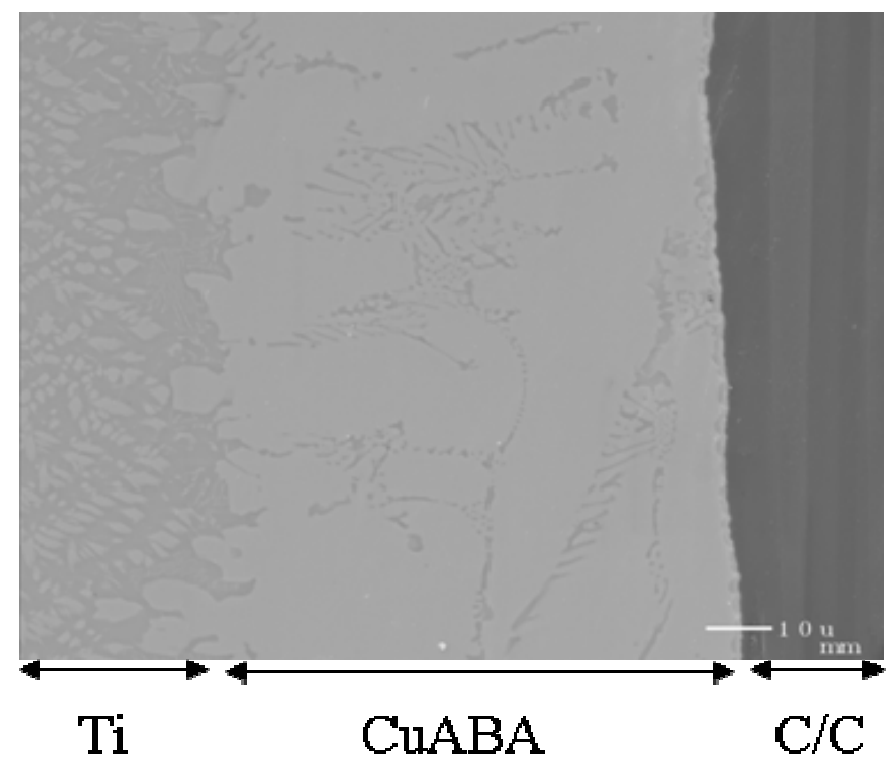

Fig. 2: Microstructure of Ti/Cu-ABA/C-C composite interface region.

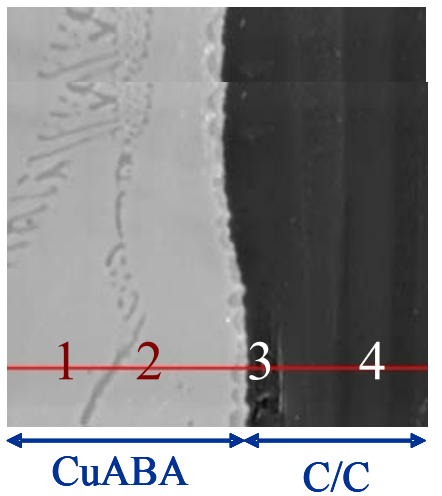

Composition:

1) $38 \mathrm{at} \% \mathrm{Cu}, 54 \mathrm{at} \% \mathrm{Ti}, 4 a t \% \mathrm{Si}, 4 \mathrm{at} \% \mathrm{Al}$

2) $65 \mathrm{at} \% \mathrm{Ti}, 26 \mathrm{at} \% \mathrm{Cu}, 5 \mathrm{at} \% \mathrm{Si}, 4 \mathrm{at} \% \mathrm{Al}$

3) $78 \mathrm{at} \% \mathrm{Ti}, 17 \mathrm{at} \% \mathrm{Cu}, 3 \mathrm{at} \% \mathrm{Si}, 2 \mathrm{at} \% \mathrm{Al}$

4) $100 \mathrm{at} \% \mathrm{C}$

(a)

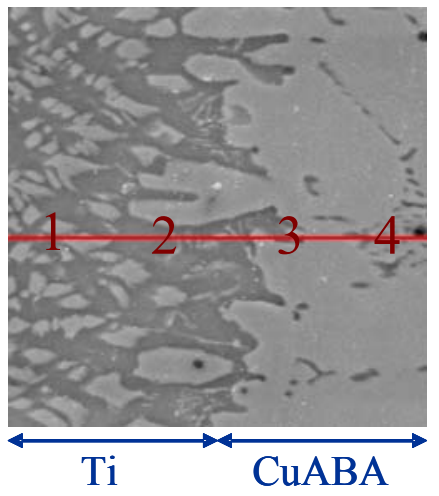

(b)

Composition:

1) $80 \mathrm{at} \% \mathrm{Ti}, 13 \mathrm{at} \% \mathrm{Cu}, 6 \mathrm{at} \% \mathrm{Al}, 1 \mathrm{at} \% \mathrm{Si}$

2) $86 \mathrm{at} \% \mathrm{Ti}, 11 \mathrm{at} \% \mathrm{Cu}, 2 \mathrm{at} \% \mathrm{Al}, 1 \mathrm{at} \% \mathrm{Si}$

3) $61 \mathrm{at} \% \mathrm{Ti}, 35 \mathrm{at} \% \mathrm{Cu}, 2 \mathrm{at} \% \mathrm{Al}, 2 \mathrm{at} \% \mathrm{Si}$

4) $57 \mathrm{at} \% \mathrm{Ti}, 40 \mathrm{at} \% \mathrm{Cu}, 1 \mathrm{at} \% \mathrm{Al}, 2 \mathrm{at} \% \mathrm{Si}$

Fig. 3 (a)\&(b): C-C/Cu-ABA and Ti/Cu-ABA interfaces, compositions (at\%) in regions marked. 


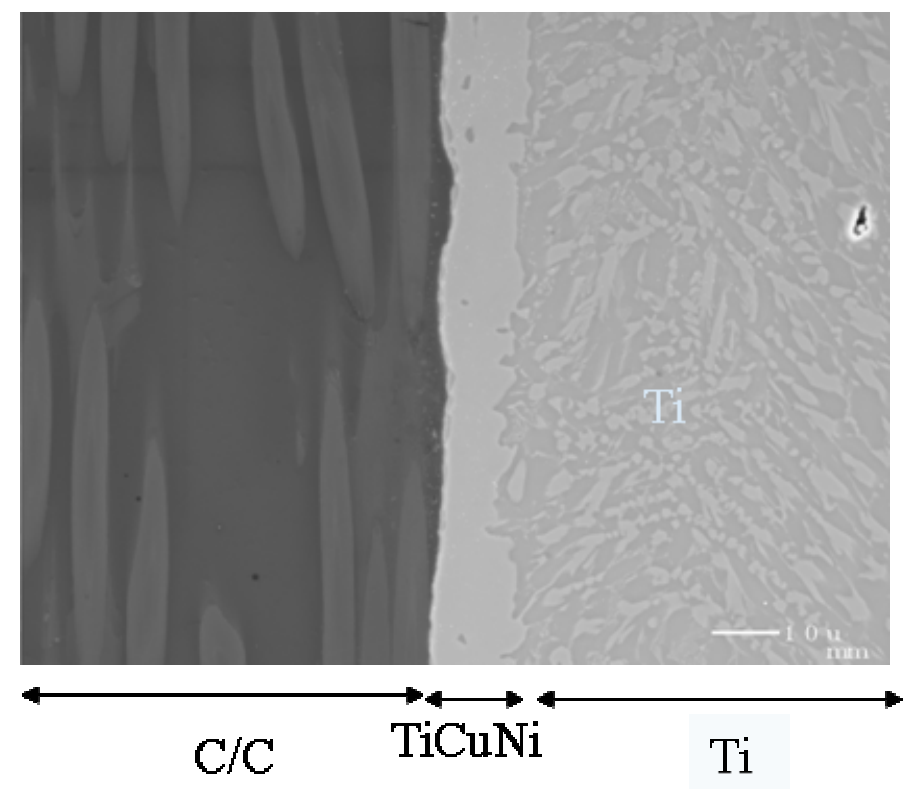

Fig. 4 Microstructure of Ti/TiCuNi/C-C composite interface region.

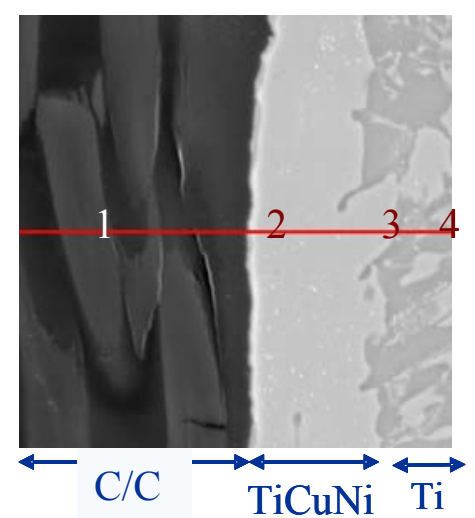

Composition:
1) $100 \mathrm{at} \% \mathrm{C}$
2) $61 \mathrm{at} \% \mathrm{Ti}, 28 \mathrm{at} \% \mathrm{Cu}, 11 \mathrm{at} \% \mathrm{Ni}$
3) $40 \mathrm{at} \% \mathrm{Ti}, 33 \mathrm{at} \% \mathrm{Cu}, 27 \mathrm{at} \% \mathrm{Ni}$
4) $50 \mathrm{at} \% \mathrm{Ti}, 26 \mathrm{at} \% \mathrm{Cu}, 24 \mathrm{at} \% \mathrm{Ni}$

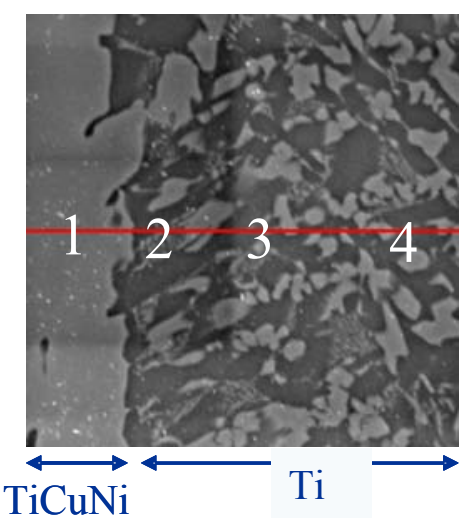

(b)

Composition:

1) $44 \mathrm{at} \% \mathrm{Ti}, 24 \mathrm{at} \% \mathrm{Ni}, 32 \mathrm{at} \% \mathrm{Cu}$

2) $41 \mathrm{at} \% \mathrm{Ti}, 22 \mathrm{at} \% \mathrm{Ni}, 37 \mathrm{at} \% \mathrm{Cu}$

3) $57 \mathrm{at} \% \mathrm{Ti}, 16 \mathrm{at} \% \mathrm{Ni}, 27 \mathrm{at} \% \mathrm{Cu}$

4) $43 \mathrm{at} \% \mathrm{Ti}, 35 \mathrm{at} \% \mathrm{Ni}, 22 \mathrm{at} \% \mathrm{Cu}$

Fig. 5 (a) \& (b): C-C/TiCuNi and Ti/TiCuNi interfaces, compositions (at\%) in regions marked. 


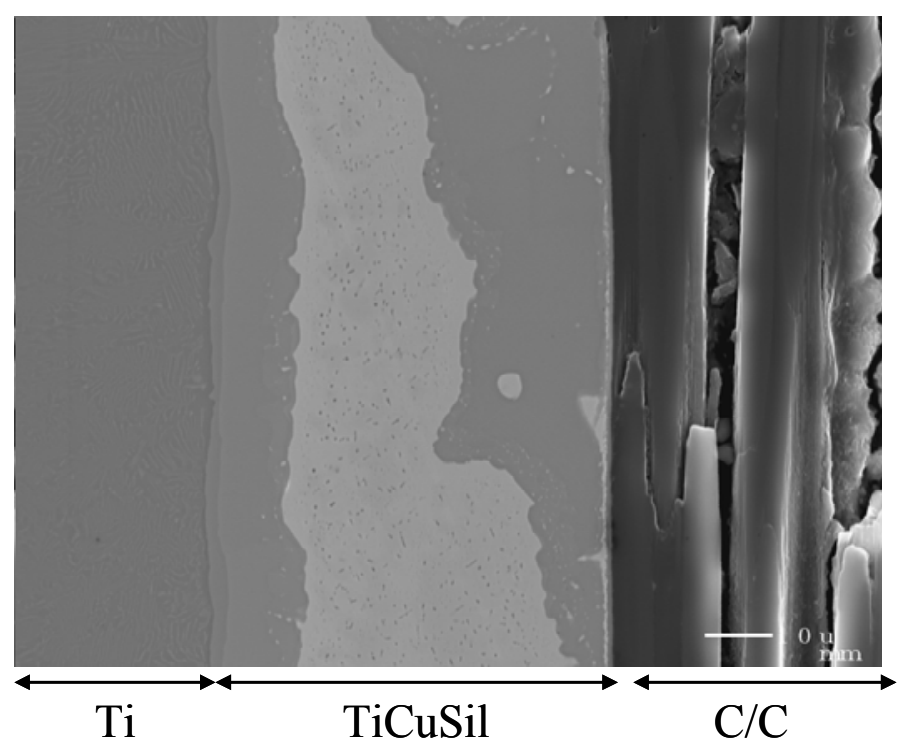

Fig. 6: Microstructure of Ti/TiCuSil/C-C composite interface showing secondary phase precipitation.

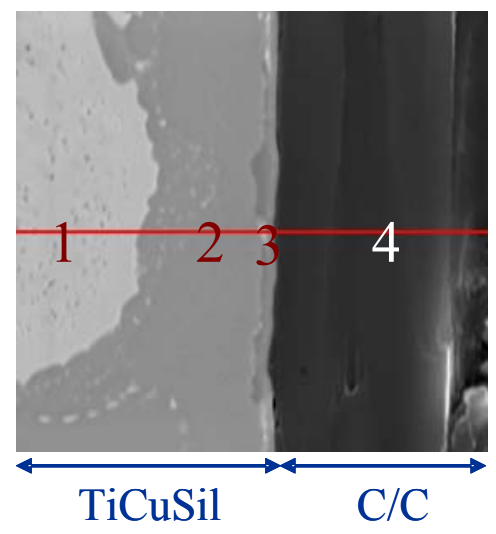

Composition:

1) $84 \mathrm{at} \% \mathrm{Ag}, 9 \mathrm{at} \% \mathrm{Cu}, 7 \mathrm{at} \% \mathrm{Ti}$

2) $8 \mathrm{at} \% \mathrm{Ag}, 54 \mathrm{at} \% \mathrm{Cu}, 38 \mathrm{at} \% \mathrm{Ti}$

3) $24 \mathrm{at} \% \mathrm{Ag}, 76 \mathrm{at} \% \mathrm{Ti}$

4) $100 \mathrm{at} \% \mathrm{C}$

(a)

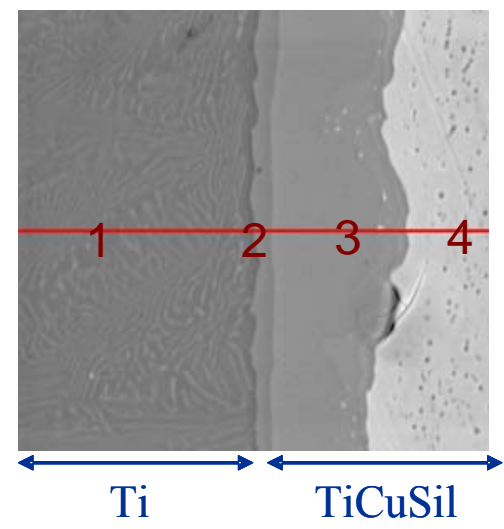

Composition:

1) $87 \mathrm{at} \% \mathrm{Ti}, 13 \mathrm{at} \% \mathrm{Ag}$

2) $52 \mathrm{at} \% \mathrm{Ti}, 29 \mathrm{at} \% \mathrm{Cu}, 19 \mathrm{at} \% \mathrm{Ag}$

3) $38 \mathrm{at} \% \mathrm{Ti}, 48 \mathrm{at} \% \mathrm{Cu}, 14 \mathrm{at} \% \mathrm{Ag}$

4) $6 \mathrm{at} \% \mathrm{Ti}, 94 \mathrm{at} \% \mathrm{Ag}$

Fig. 7 (a) \& (b): C-C/TiCuSil and Ti/TiCuSil interfaces, compositions (at\%) in regions marked. 


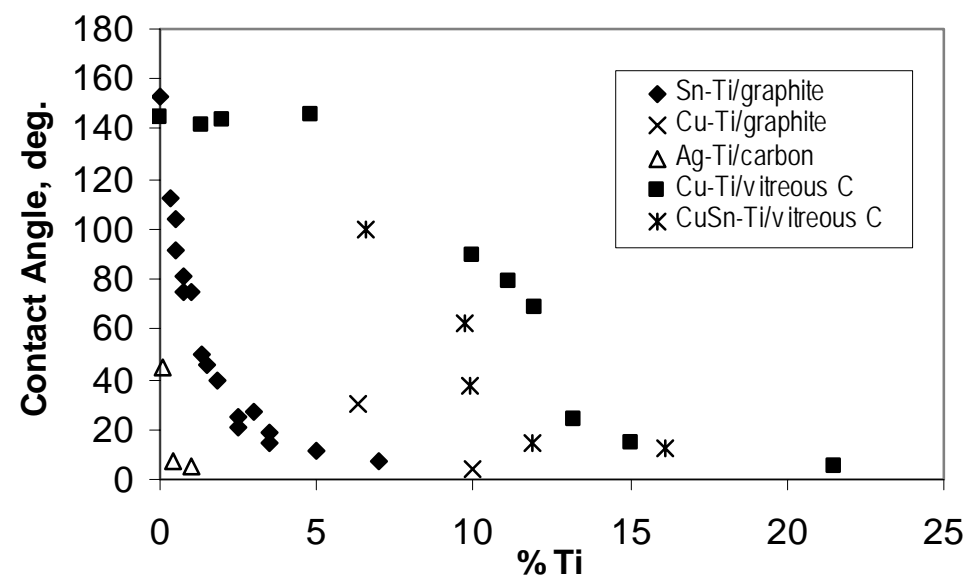

Fig. 8: Effect of Ti on the contact angle of carbon with some metals. Data are from studies cited in ref. $[9,11,12,15,20]$.

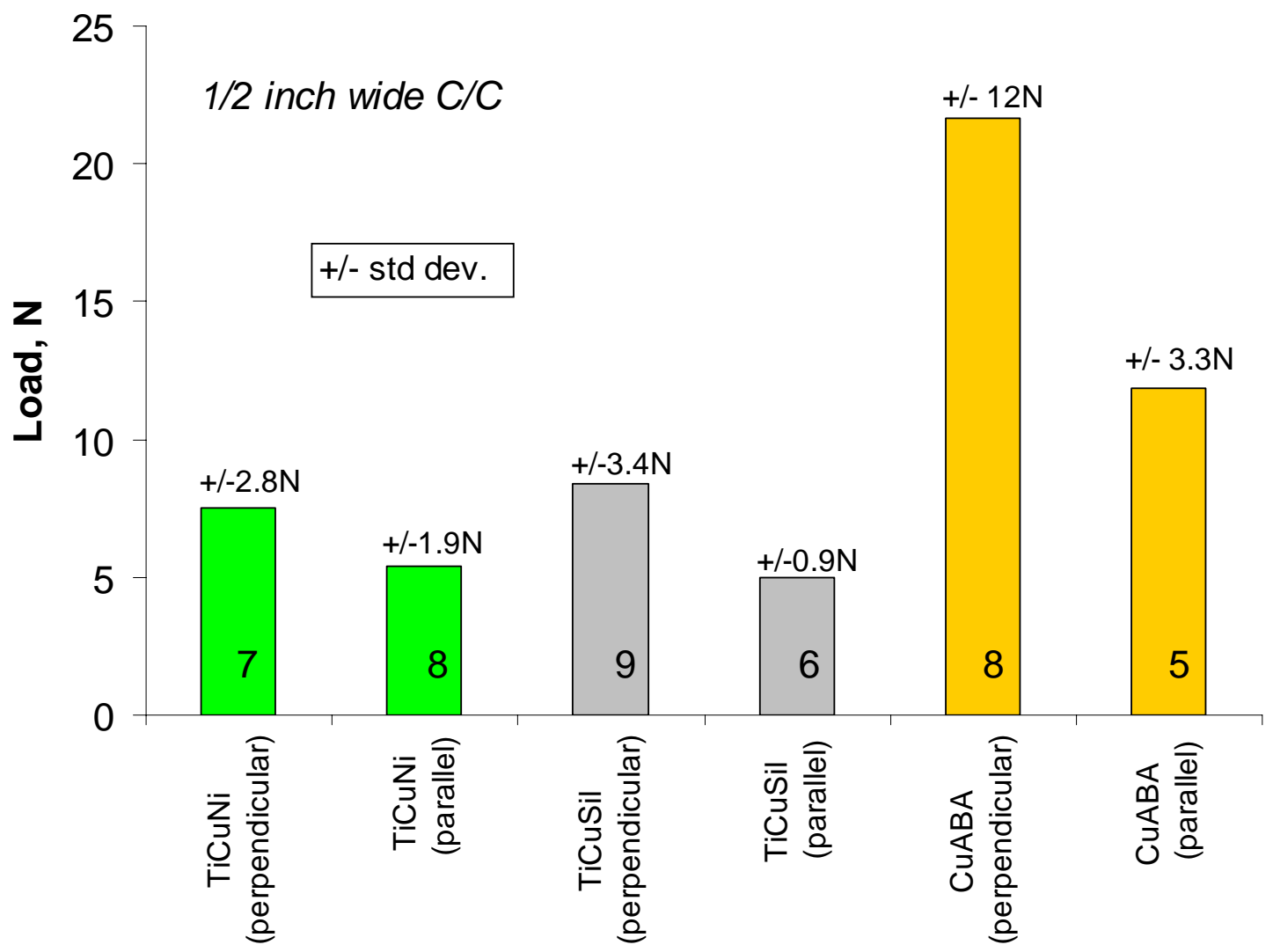

Figure 9: Tensile failure loads of C-C plate, Ti-tube joints. 

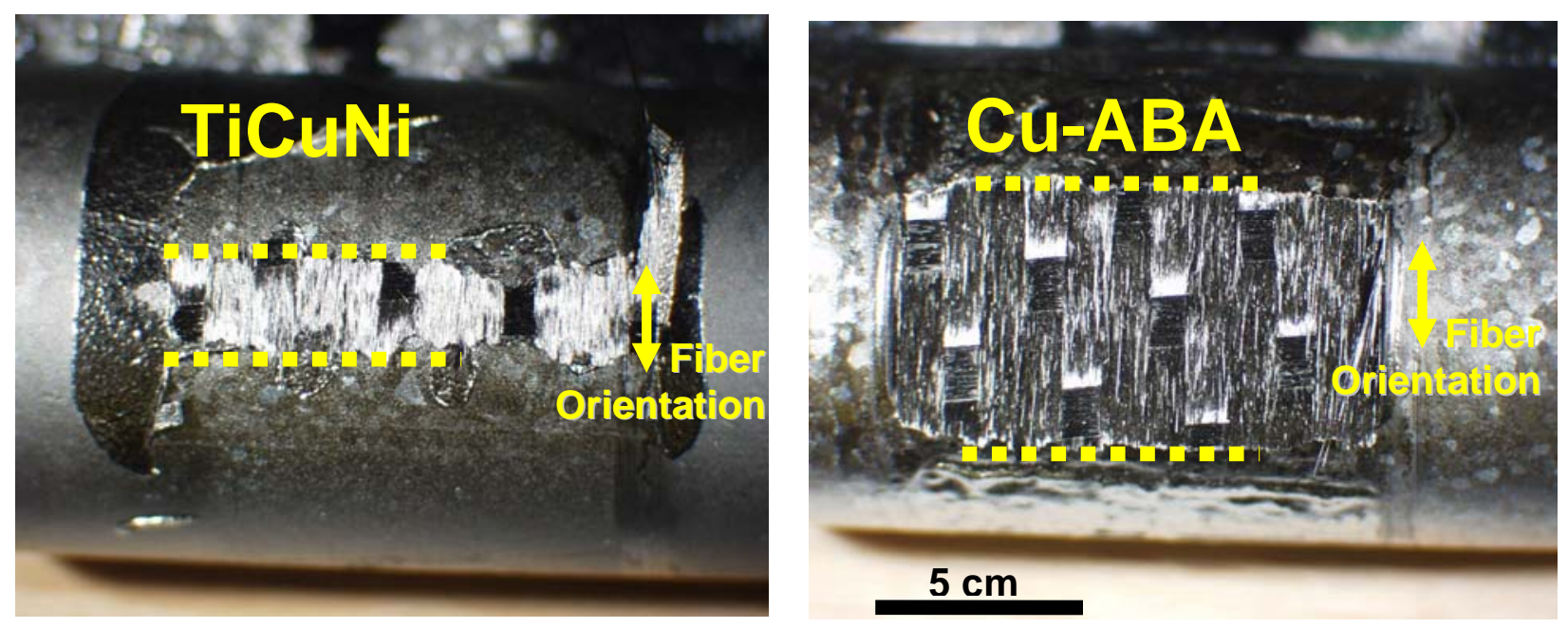

Figure 10: Typical fracture surfaces of TiCuNi and $\mathrm{Cu}-\mathrm{ABA} \mathrm{C}-\mathrm{C}$ plate/Ti-tube joint structures. The fiber tows in the surface ply of the $\mathrm{C}-\mathrm{C}$ composite was oriented perpendicular to the tube axis. The dotted lines show the size of the bonded area for the braze material. 